\title{
ANALISIS TINGKAT KESEHATAN PT. PERKEBUNAN NUSANTARA IV TAHUN 2016-2018
}

\section{ANALYSIS OF HEALTH LEVEL PT. PERKEBUNAN NUSANTARA IV IN 2016-2018}

\section{Laula Dwi Marthika}

\author{
Progam Studi Akuntansi, Fakultas Ekonomi, Universitas Muara Bungo \\ Jl. Diponegoro No 27 Kelurahan Cadika, Kecamatan Rimbo Tengah Kabupeten Bungo, \\ Jambi 37211, Indonesia \\ laula_dm@yahoo.co.id
}

\begin{abstract}
ABSTRAK
Penelitian ini bertujuan untuk mengetahui tingkat kesehatan PT. Perkebunan Nusantara IV pada Tahun 2016 sampai 2018. Penilaian tingkat Kesehatan Perusahaan berdasarkan Keputusan Menteri BUMN Nomor: KEP-100/MBU/2002. Berdasarkan surat keputusan tersebut tingkat kesehatan dilihat dari tiga aspek, yaitu: aspek keuangan, aspek operasional dan aspek administratif

Metode analisis data yang digunakan dalam penelitian ini adalah analisis deskriptif untuk mengetahui tingkat kesehatan keuangan berdasarkan 3 aspek, yaitu aspek keuangan. aspek operasional dan aspek administratif.

Secara keseluruhan tingkat kesehatan PT. Perkebunan Nusantara IV berada pada predikat sehat dengan katagori "A". Namun jika melihat ketiga aspeknya dari tahun 20162018, aspek keuangan dan operasional mengalami penurunan sedangakan aspek adeministratif konstan. Pada aspek keaungan Rasio Keuangan ROE, ROI, Rasio Kas dan perputaran total aset yang mengalami penurunan dari total 8 rasio keuangan yang dihitung. Aspek Operasional Tahun 2018 mengalami penuruan dari tahun 2017 ke tahun 2018. Produktivitas Hasil kebun dan Produktivitas Tenaga Kerja pada Kebun Teh mengalami penurunan. Dari nilai 80 menjadi 50 pada produktivitas hasil kebun teh (Daun Teh Basah) dan dari 100 menjadi 50 pada produktivitas tenaga kerja kebun teh (Ton/Orang).

Kata Kunci: Tingkat Kesehatan. Keuangan, Operasional, Administrasi
\end{abstract}

\section{ABSTRACT}

This study aims to determine the health level of PT. Perkebunan Nusantara IV in 2016 to 2018. Assessment of the level of company health is based on the Decree of the Minister of BUMN Number: KEP-100 / MBU / 2002. Based on the decree, the health level is seen from three aspects, namely: financial aspects, operational aspects and administrative aspects

The data analysis method used in this research is descriptive analysis to determine the level of financial health based on 3 aspects, namely financial aspects. operational aspects and administrative aspects.

Overall health level of PT. Perkebunan Nusantara IV is in the predicate of "healthy" with the category "A". However, if you look at the three aspects from 2016-2018, the financial and operational aspects experienced a decline, while the administrative aspects were constant. In the financial aspect, ROE, ROI, cash ratio and total asset turnover have decreased from a total of 8 calculated financial ratios. Operational Aspects of 2018 experienced a decrease from 2017 to 2018. Productivity of farm products and labor productivity in tea gardens decreased. From a value of 80 to 50 in the productivity of tea 
garden products (Wet Tea Leaves) and from 100 to 50 in the productivity of tea garden labor (tonnes / person).

Keywords: Health Level. Finance, Operations, Administration

\section{PENDAHULUAN}

Bada Usaha Milik Negara atau yang disingkat BUMN adalah Badan Usaha yang seluruh atau sebagian modalnya dimiliki negara melalui penyertaan modal secara langsung dari kekayaan negara yang dipisahkan (Undang-Undang No 19 Tahun 2003). Walaupun BUMN merupakan milik negara, penyertaan modalnya dilakukan oleh negara, tidak sedikit BUMN yang mengalami kerugian dan terancam bangkrut.

PT Krakatau Steel Tbk merupakan BUMN yang bergerak dibidang Produksi Baja, Perusahaan baja pelat merah ini mencatatkan rugi sebesar 211,91 juta dollar AS atau sekitar Rp 2,96 triliun (kurs Rp 14.000) pada kuartal III 2019. Di periode yang sama tahun lalu, Krakatau Steel juga menderita kerugian sebesar 37,38 juta dollar AS atau sekitar Rp 523,34 miliar. Kerugian perseroan tersebut membengkak 467 persen dari periode sama tahun lalu. Laporan keuangan yang berdarah-darah sejak lama ini salah satunya akibat kesulitan bersaing dengan baja impor.

Masalah utama yang dihadapi terdapat pada aspek modal yang terbatas dan sulitnya mendapatkan fasilitas pembiayaan usaha (Rahmalia,et al., 2016). Walaupun Perusahaan yang memiliki kode emiten KRAS ini pernah mendapatkan suntikan modal PMN sebesar Rp 1,5 triliun pada tahun 2016, namun masih tetap mengalami kerugian.

Di sektor pertanian, jika memlihat pada PT. Petani, walaupun sudah mendapat kucuran pada tahun 2016 menerima kucuran PMN sebesar 240 miliar. Di tahun 2018, perusahaan menderita kerugian sebesar Rp 83 miliar. PT Petani sendiri menjadi sorotan Menteri Keuangan, Sri Mulyani, Sri Mulyani mengatakan Ada dua kelompok BUMN yang masuk kategori distress (darurat) yaitu aneka industri dan pertanian. Dari 5 BUMN Yang terdaftar Bursa Efek Indonesia ada 3 BUMN yang dikategorikan rentan bangkrut. Formula Z-Score untuk memprediksi kebangkrutan dari Altman merupakan sebuah multivariate formula yang digunakan untuk mengukur kesehatan finansial dari sebuah perusahaan (Kasmir, 2012). Seperti yang dikatakn, menteri keungan Sri Mulyani, dengan perhitungan Z-Score. PT Perkebunan Nusantara III (Persero) Z-Score 0,35, PT Pertani (Persero) Z-Score 0,82, dan PT Sang Hyang Seri (Persero) Z-Score -14.02. Dalam sektor ini hanya dua perusahaan yang masuk dalam Z-Score hijau yaitu PT Perikanan Nusantara (Persero) Z-Score 4,14 dan Perum Perikanan Indonesia ZScore 6,56.

Untuk menilai tingkat kesehatan BUMN dan mencegah terjadinya kebangkrutan, Menteri Badan Usaha Milik Negara dapat mendorong perusahaan ke arah peningkatan efisiensi dan daya saing, mengeluarkan standar penilaian kinerja perusahaan BUMN yang tidak hanya terfokus pada penilaian kinerja keuangan, yang tertuang dalam Keputusan Menteri BUMN Nomor: KEP100/MBU/2002 tentang penilaian Tingkat Kesehatan Badan Usaha Milik Negara. Tingkat kesehatan BUMN ditetapkan berdasarkan penilaian terhadap kinerja perusahaan untuk tahun buku bersangkutan yang meliputi penilaian dari aspek 
keuangan, aspek operasional, dan aspek administrasi.

PT Perkebunan Nusantara IV (Persero) adalah Perusahaan Badan Usaha Milik Negara yang berkantor pusat di Medan, Sumatra Utara dan resmi berdiri pada tahun 1996 sebagai peleburan beberapa perusahaan lain. Perkebunan Nusantara IV adalah salah satu perusahaan yang bergerak dibidang agrobisnis dan agroindustri. Dalam menjalankan bisnisnya PTPN IV mengelola 2 segmen usaha komoditi perkebunan yaitu (Fauziah, 2013) : Segmen Usaha Komoditi Kelapa Sawit dan Segmen Usaha Komoditi Teh. Jika melihat dari perkembangan laba kotor dari tahun 2016 sampai 2018 (Anual Repot Perusahaan), sebagai berikut:

\section{Gambar 1. Laba Kotor PT. \\ Perkebunan Nusantara IV 2016- 2018}

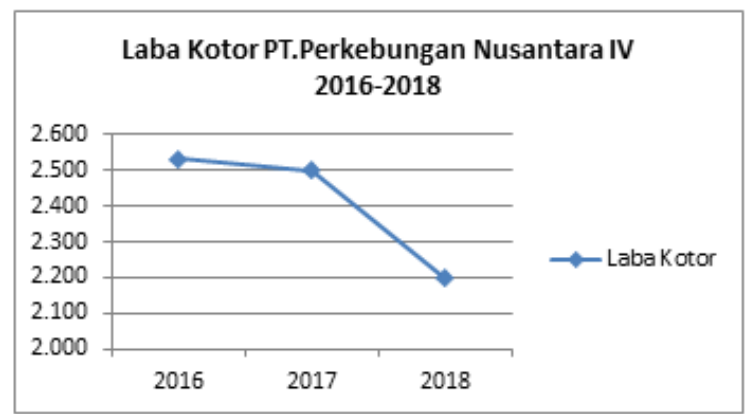

Sumber: Anual Report PT. Perkebunan Nusantara IV 2018 (Dalam Triliun Rupiah)|

Dari Gambar Grafik terlihat bahwa Laba kotor PT. Perkebunan Nusantara dari tahun 2016-2018 mengalami penurunan. Hal ini juga akan mengakibatkan tingkat profitabilitas perusahaan atau kemampuan perusahaan menghasilkan laba (Harahap, 2008), profitabilitas adalah kemampuan perusahaan yang menggambarkan perolehan laba melalui semua. Apabila terjadi penuruan laba setiap tahunnya. Akan menyebabkan terjadinya penurunan deviden yang didapat oleh investor. hal ini merupakan pendapat Baridwan (2014). Besaran yang diterima pemegang saham bisa mengalami perubahan setiap tahun, sesuai dengan laba tahun- tahun tersebut dan keputusan Rapau Umum Pemegang Saham (RUPS)

Berdasarkan masalah tersebut, penelitian ini mengambil judul "ANALISIS TINGKAT KESEHATAN PT. PERKEBUNAN NUSANTARA IV TAHUN 2016-2018". Dengan tujuan penelitian adalah untuk menganalisis kesehatan PT. Perkebunan Nusantara IV tahun 2012-2018 berdasarkan Keputusan Menteri BUMN Nomor: KEP100/MBU/2002 tentang penilaian Tingkat Kesehatan Badan Usaha Milik Negara.

\section{METODE PENELITIAN}

Metode Penelitian yang digunakan pada penelitian ini adalah metode analisis deskriptif (Sugiyono. 2012). Analisis deskriptif ini mengukur tingkat kesehatan perusahaan berdasarkan 3 aspek yaitu: aspek keuangan, aspek operasional, dan aspek administrasi. Penilaian tingkat kesehatan BUMN digolongkan menjadi:

1. Sehat, yang terdiri dari:
a. AAA apabila total (TS) $>95$
b. AA apabila $80<\mathrm{TS}<=95$
c. A apabila $65<\mathrm{TS}<=80$

2. Kurang sehat, yang terdiri dari:
a. BBB apabila $50<\mathrm{TS}<=65$
b. BB apabila $40<\mathrm{TS}<=50$
c. apabila $30<\mathrm{TS}<=40$

d. Tidak sehat, yang terdiri dari:
a. CCC apabila $20<\mathrm{TS}<=30$
b. $\mathrm{CC}$ apabila $10<\mathrm{TS}<=20$
c. $\mathrm{C}$ apabila $\mathrm{TS}<=10$

Tata Cara Penilaian Tingkat Kesehatan BUMN Non Jasa Keuangan 
1. Aspek Keuangan

Tabel 1. Tingkat Kesehatan Keuangan

\begin{tabular}{llcc}
\hline No & Indikator & \multicolumn{2}{c}{ Bobot } \\
\cline { 3 - 4 } & & Infra & $\begin{array}{c}\text { Non } \\
\text { Infra }\end{array}$ \\
\hline 1 & Imbalan Kepada & 15 & 20 \\
& $\begin{array}{l}\text { Pemegang Saham } \\
\text { (ROE) }\end{array}$ & & \\
2 & Imbalan Investasi (ROI) & 10 & 15 \\
3 & Rasio Kas & 3 & 5 \\
4 & Rasio Lancar & 4 & 5 \\
5 & Collection Periods & 4 & 5 \\
6 & Perputaran Persediaan & 4 & 5 \\
7 & Perputaran Total Asset & 4 & 5 \\
8 & Rasio Model Sendidi & 6 & 10 \\
& Tehadap Modal Aktiva & & \\
\hline \multicolumn{2}{c}{ Total } & 50 & 70 \\
\hline
\end{tabular}

Sumber: Keputusan Menteri BUMN Nomor: KEP-100/MBU/2002

2. Aspek Operasional

Total Bobot Aspek Operasional adalah:

a. BUMN Infrastruktur Jumlah Total 35 Point

b. BUMN Non Infrastruktur Jumlah Total 15 Point

HASIL DAN PEMBAHASAN

HASIL

1. Tingkat Kesehatan Berdasarkan Aspek Keuangan
3. Aspek Administratif

Tabel 2. Tingkat Kesehatan

Administratif

\begin{tabular}{llcc}
\hline No & Indikator & \multicolumn{2}{c}{ Bobot } \\
\cline { 3 - 4 } & & Infra & $\begin{array}{c}\text { Non } \\
\text { Infra }\end{array}$ \\
\hline 1 & Laporan Perhitungan & 3 & 3 \\
& Tahunan & & \\
2 & Rancangan RKAP & 3 & 3 \\
3 & Laporan Periodik & 3 & 3 \\
4 & Kinerja PUKK & 6 & 6 \\
\hline Total & 15 & 15 \\
\hline
\end{tabular}

Sumber: Keputusan Menteri BUMN

Nomor: KEP-100/MBU/2002

Dikarenakan PT. Perkebunan Nusantara IV meruapakan BUMN yang bergerak bidang pertanian bukan bergerak dibidang infrastruktur, maka indikator yang digunakan untuk menilai tingkat kesehatan baik aspek keuangan, aspek Operasional dan Aspek Administratif menggunakan katagori perusahaan non infra struktur.

Tabel Penilaian Aspek Keuangan PT. PN IV Tahun berdasarkan Keputusan Menteri BUMN Nomor KEP-100/MBU/2002

Tabel 3. Tingkat Kesehatan Keuangan PT. Perkebunan Nusantara IV Tahun 2016-2018

\begin{tabular}{lrccccc}
\hline \multirow{2}{*}{ INDIKATOR ASPEK KEUANGAN } & \multicolumn{2}{c}{2016} & \multicolumn{2}{c}{2017} & \multicolumn{2}{c}{2018} \\
\cline { 2 - 7 } & Nilai & Skor & Nilai & Skor & Nilai & Skor \\
\hline Rasio ROE & 8,77 & 12 & 7,47 & 10 & 6,36 & 10 \\
Rasio ROI & 13,62 & 12 & 12,79 & 10,5 & 10,58 & 9 \\
Rasio Lancar & 121,97 & 4 & 93,10 & 2 & 99,11 & 2 \\
Rasio Kas & 65,97 & 5 & 34,93 & 4 & 15,13 & 3 \\
Collection Period & 2,72 & 5 & 3,56 & 5 & 22,89 & 5 \\
Perputaran Persediaan & 33,15 & 4,5 & 36,42 & 4,5 & 40,45 & 5 \\
Perputaran Total Aset & 38,58 & 5 & 38,83 & 5 & 30,58 & 5 \\
Rasio Modal Sendiri Teradap Total Aktiva & 46,64 & 2,5 & 47,28 & 2,5 & 45,61 & 2,5 \\
\hline & & 50 & & 43,5 & & 41,5 \\
\hline
\end{tabular}

Sumber: Data Olahan 2020 
Gambar 2 Grafik Tingkat Kesehatan Keuangan PT. Perkebunan Nusantara IVTahun 2016-2018

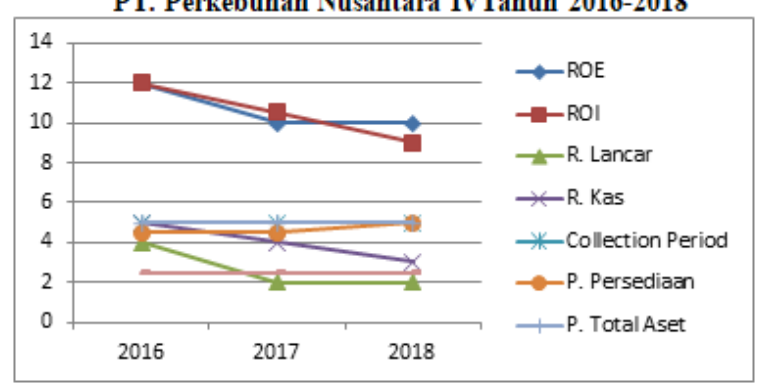

Sumber : Data Olahan 2020

Tabel dan Grafik menunjukkan bahwa kinerja keuangan PT.PN IV selama tahun 2016 sampai dengan 2018dari 8 indikator aspek keuangan, 5 mengalami penurunan.
Sedangkan 3 indikator lainnnya seperti Collection Period, Perputaran Total aset dan Rasio Modal Sendiri terhadap Total Aktiva mengalami posisi tidak berubah. Secara total tingkat kesehatan dalam aspek keuangan mengalami penurunan.

\section{Tingkat Kesehatan Berdasarkan Aspek Operasional}

Tabel Penilaian Aspek Operasional PT. PN IV Tahun berdasarkan Keputusan Menteri BUMN Nomor KEP100/MBU/2002:

Tabel 4. Tingkat Opersional Keuangan PT. Perkebunan Nusantara IVTahun 2016-2018

\begin{tabular}{lcccccc}
\hline \multirow{2}{*}{ INDIKATOR ASPEK KEUANGAN } & \multicolumn{2}{c}{2016} & \multicolumn{2}{c}{2017} & \multicolumn{2}{c}{2018} \\
\cline { 2 - 7 } & Nilai & Skor & Nilai & Skor & Nilai & Skor \\
\hline Produktivitas Hasil Kebun & & & & & & \\
\hline TBS & 80 & 3,2 & 80 & 3,2 & 80 & 3,2 \\
Daun Teh Basah (DTB) & 80 & 0,8 & 80 & 0,8 & 50 & 0,5 \\
& & & & & & \\
\hline Rendemen Hhasil Olahan & 80 & 3,2 & 80 & 3,2 & 80 & 3,2 \\
\hline Minyak Sawit & 100 & 1 & 100 & 1 & 100 & 1 \\
Teh Kering & & & & & & \\
\hline Produktivitas Tenaga Kerja (Ton/Orang) & & & & & & \\
\hline Kelapa Sawit & 80 & 3,2 & 100 & 4 & 100 & 4 \\
Teh & 100 & 1 & 100 & 1 & 50 & 0,5 \\
& & 12,4 & & 13,2 & & 12,4 \\
\hline
\end{tabular}

Sumber Data Olahan, 2020 


\section{Gambar 3. Grafik Tingkat KesehatanBerdasarkan Aspek Operasional PT.} PerkebunanNusantara IV Tahun 2016-2018

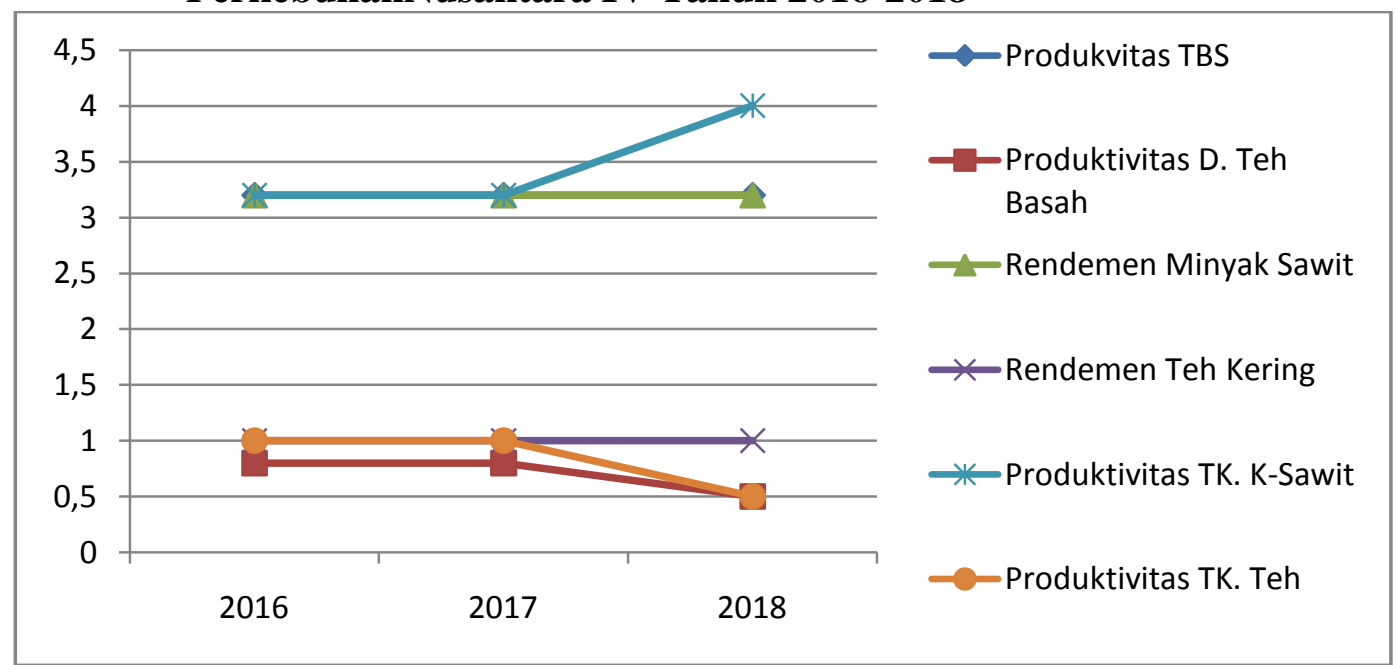

\section{Sumber Data Olahan 2020}

Tabel dan Grafik menunjukkan bahwa kinerja keuangan PT.PN IV selama tahun 2016 sampai dengan 2018dari 8 indikator aspek keuangan, 5 mengalami penurunan. Sedangkan 3 indikator lainnnya seperti Collection Period, Perputaran Total aset dan Rasio Modal Sendiri terhadap Total Aktiva mengalami posisi tidak berubah.
Secara total tingkat kesehatan dalam aspek keuangan mengalami penurunan.

\section{Tingkat Kesehatan Berdasarkan} Aspek Administratif

Tabel Penilaian Aspek Administratif PT. PN IV Tahun berdasarkan Keputusan Menteri BUMN Nomor KEP-100/MBU/2002

Tabel 5. Tingkat Opersional Keuangan PT. Perkebunan Nusantara IV Tahun 2016-2018

\begin{tabular}{lcccccc}
\hline \multirow{2}{*}{ INDIKATOR ASPEK KEUANGAN } & \multicolumn{2}{c}{$\mathbf{2 0 1 6}$} & \multicolumn{2}{c}{$\mathbf{2 0 1 7}$} & \multicolumn{2}{c}{$\mathbf{2 0 1 8}$} \\
\cline { 2 - 6 } & Nilai & Skor & Nilai & Skor & Nilai & Skor \\
\hline Laporan Perhitungan Tahunan & On Time & 3 & On Time & 3 & On Time & 3 \\
Rancangan RKAP & On Time & 3 & On Time & 3 & On Time & 3 \\
Laporan Periodik & On Time & 3 & On Time & 3 & On Time & 3 \\
PUKK & & & & & & \\
$\quad$ Efektivitas Penyaluran & 43,99 & 2 & 96,28 & 3 & 100 & 3 \\
$\quad$ Tingkat Kolektivitas Pengembalian & & & & & & \\
Pinjaman & 70,18 & 3 & 45,63 & 2 & 55 & 2 \\
& & 14 & & 14 & & 14 \\
\hline
\end{tabular}

\section{Sumber : data Olahan, 2020}

Berdasarkan tabel diatas, berdasarkan aspek administratif, PTPN VI sudah sangat sehat. Laproan keuangan Tahunan, Rancangan RKAP, Laporan Periodik sudah di laporkan dengan tepat waktu oleh perusahaan. Untuk kondisi Efektivitas Penyaluran dana sudah berjalan dengan baik. Peningkatan efektivitas penyaluran dana 2 kali lipat terjadi di tahun 2017 dan tetap membaik di tahun 2018. Namun ditingkat kolektivitas pengembalian Pinjaman menglamai penurunan dari $70 \%$ ke $45 \%$ ditahun 2017. Walaupun menigkat persetasenya ditahun 2018. 
Namun masih dirange yang sama dengan skor 2 ditahun 2018.

\section{Tingkat Kesehatan Berdasarkan Aspek Keuangan, Operasional dan Administratif}

Tabel Penilaian Aspek Keuangan, Operasional dan Administrasi PT. PN IV Tahun berdasarkan Keputusan Menteri BUMN Nomor KEP-100/MBU/2002:

Tabel 6. Tingkat Keuangan Aspek Keuangan, Operasional dan Administrasi PT. Perkebunan Nusantara IV Tahun 2016-2018

\begin{tabular}{lccc}
\hline Aspek Tingkat & \multicolumn{3}{c}{ Total Skor } \\
\cline { 2 - 4 } Kesehatan & 2016 & 2017 & 2018 \\
\hline Aspek & 50,0 & 43,5 & 41,5 \\
$\begin{array}{l}\text { Keuangan } \\
\text { Aspek }\end{array}$ & 12,4 & 13,2 & 12,4 \\
$\begin{array}{l}\text { Operasional } \\
\text { Aspek }\end{array}$ & 14,0 & 14,0 & 14,0 \\
Administratif & & & \\
Total & 76,4 & 70,7 & 67,9 \\
Kategori & A & A & A \\
Predikat & Sehat & Sehat & Sehat \\
\hline
\end{tabular}

Sumber: Data Olahan, 2020.

Tabel menunjukkan bahwa penilaian tingkat kesehatan PT. Perkebunan Nusantara IV berdasarkan Keputusan Menteri BUMN Nomor: KEP100/MBU/2002. Memperoleh tingkat kesehehatan dengan katagori " $A$ " dan predikat "Sehat".

\section{Pembahasan Tingkat Kesehatan Berdasarkan Aspek Keuangan, Operasional dan Administratif}

Tabel menunjukkan bahwa penilaian tingkat kesehatan PT. Perkebunan Nusantara IV berdasarkan Keputusan Menteri BUMN Nomor: KEP100/MBU/2002. Memperoleh tingkat kesehatan Dengan Pedikat A dan katagori "Sehat". Namun harus diperhatikan bahwa total nilai tingkat kesehatan dari tahun 2016 ke tahun 2018 mengalami penurunan.
Penurunan kinerja ini dipengaruhi ileh penurunan kinerja aspek keuangan. Aspek Keuangan dari tahun ke tahun mengalami penurunan yang sangat drastis.

\section{Tingkat Kesehatan Berdasarkan Aspek Keuangan}

Tingkat Kesehatan berdasarkan aspek keuangan menggunakan analisis laporan keuangan. Analisis laporan keuangan mengacu pada hubungan yang diungkapkan dalam istilah matematikaantara dua tokoh individu atau kelompok tokoh terhubung satu sama lain secara logis dan dipilihdari laporan keuangan yang menjadi perhatiannya (Buvaneswarin \& Lakshmi, 2015).

Pada Aspek keuangnan :Rasio ROE, Rasio ROI, Rasio Lancar, Rasio Kas serta rasio modal terhadap total aset mengalami penurunan. Penurunan ini sangat drastis.

Aspek yang membuat penurunan drastis ini adalah dikarenakan penjualan atau total pendapatan perusahaan mengalami penurunan, penurunan $7 \%$ dari tahun 2017. Yang semula 5.620 Triliun menjadi 5.224 Triliun. Hal ini dikarenakan Selama tahun 2018, harga CPO yang merosotsejak bulan Juni 2018, dari ratarata tahun 2017 sebesar $\mathrm{Rp} 8.300 / \mathrm{kg}$ turun terus dan sempat menyentuh Rp5.400/kg. Tidak hanya itu ada juga tantangan peningkatan bea impor masuk di India menjadi $44 \%$, anjloknya harga minyak mentah, dampakperang dagang China dan Amerika, serta isu sustainability.

Usaha Kelapa Sawit dan CPO merupakan Objek Vital bagi PTPN IV. Sementara pada kebun teh juga menjadi andalan, walaupun hanya memiliki 3 perkebunan teh. Pada harga teh tahun 2018 tidak mengalami penurunan. Sehingga dari sisi harga tahun 2018 adalah konstan.

\section{Tingkat Kesehatan Berdasarkan Aspek Operasional}

Pada aspek operasional bisa dilihat bahwa pada tahun 2017, skor tingkat kesehatan mengalami kenaikan, namun 
pada 2018 terjadi penurunan. Penurunan yang signifikan terjadi pada usaha teh. Produktivitas Daun Teh Basah Mengalami penurunan dari nilai 80 ke 50, Hampir $50 \%$. Hal ini juga pada produktivitas tenaga kerja. Hal ini muali dari 100 Ton per orang, turun menjadi $50 \%$ nya atau hanya 50 Ton perorang. Hal ini yang akan mengakibatkan penurunan penjualan PT. Perkebunan Nusantara IV.

Usaha Teh memang tidak menjadi objek vital jika dibandingkan dengan usaha komoditi kelapa sawit, namun jika terjadi penurunan akan membuat operasional juga akan terganggu. Usaha teh terdiri dari 2 jenis usaha, yaitu produksi dari kebun sendiri dan pembelian dari usaha petani mandiri. Pada tahun 2016-2018 produksi pada kebun sendiri tidak terjadi penurusan atau kenaikan yang signifikan, yaitu tetap berada dikisaran 1.900 ton pertahun. Tahun 2018 terjadi penurunan adalah pembelian dari usaha petani yaitu pada tahun 2019 mengalami penurunan dari lebih dari 39 ribu ton menjadi 34 ribu ton

Produksi kebun teh petani yang mulai menurun sehingga pembelian daun teh petani yang juga akan turun mengakibatkan produktivitas usaha teh dalam satuan ton perorang yang membuat turun (William, 2013; Manurung, 2012) sehingga aspek operasional tingkat kesehatan PT. Perkebunan Nusantara IV mengalami penurusan.

\section{Tingkat Kesehatan Berdasarkan Aspek Administratif}

Pada aspek administratif, tingkat kesehatan administratif bernilai 14 dari 15 skor. Hal ini disapat dengan ketepatan wkatu pelaporan laporan keuangan tahunan, laporan Rancangan RKAP dan Laporan Keuangan periodik perusahaan. Hal yang membaik adalah peningkatakn efektivitas penyaluran dana perusahaan yang meningkat pada tahun 2017 sebanyak 2 kali lipat dari 43,99 sampai 96,28. Namun pada tingkat kolektivitas pengembalian pinjaman menurun pada tahun 2017 yaitu dari 70,18 turun menjadi 45,63. Namun tingkat kolektivitas pengembalian pinjaman mengalami kenaikan lagi pada tahun 2018.

\section{KESIMPULAN}

Keputusan Menteri BUMN Nomor KEP-100/MBU/2020, Tingkat kesehatan Perusahaan dikategorikan sehat dengan kategori A. Namun dari skor penelitan mengalami penurunan setiap tahunnya dari tahun 2018 sebesar 76,4 turun menjadi 70,7 tahun 2017 dan turun kembali 67,9 pada tahun 2018. Berikut ini penjelasan tingkat kesehatan berdasrkan 3 aspek:

1. Aspek Keuangan keuangan mengalami penuruan yang paling drastis dari 2 aspek lainnya yaitu dari skor 50 (Maksimal 70) pada tahun 2016, turun menjadi 43,5 tahun 2017 dan turun kembali pada tahun 2018 menjadi 41,5.

2. Aspek Produktivitas tidak mengalami perubahan secara dratis, namun pada tahun 2017 mengalami kenaikan dari 12,4 tahun 2016 mejadi 13,2 dan tahun 2018 mengalami penurunan menjadi 12,4 .

3. Pada aspek administratif, perusahaan sudah melaporkan seluruh laporan dengan tepat waktu dan untuk efektivitas penyaluran dana dapat disalurkan dengan membaik. Sengankan kolektifitas pengembalian pinjaman mengalami penurunan setiap tahunnnya dari 2016.

\section{SARAN}

Penurunan tingkat kesehatan perusahaan yang paling tinggi dari 3 aspek adalah aspek keuangan. namun aspek keuangan tidak akan menurun apabila aspek operasionalnya mengalami kenaikan. Hal ini bisa dilihat dari data bahwa aspek operasional perusahaan mengalami penurunan terutama dalam Produktivitas Teh Basah (DTB) dan Produktivitas Tenaga Kerja perorang dalam menghasilkan Teh. Hal ini yang menjadi saran peneliti kepada peusahaan 
adalah untuk memperhatikan produktivitas teh, melakukan riset dan pengembangan pada produktivitas teh. Sehingga akan meningkatkan tingkat kesehatan perusahaaan.

Adapun yang bisa dilakukan oleh PTPN IV untuk Pengembangan agroindustri teh rakyat dapat dilakukan melalui strategi pemberdayaan kemandirian sumberdaya petani berbasisTPP (Teknologi, Permodalan, dan Pemasaran), yaitu peningkatan kemampuan dan keterampilan Teknologi hulu dan hilir serta dukungan Permodalan dan Pemasaran (Trimo dkk, 2017)

\section{DAFTAR PUSTAKA}

Baridwan, Zaki. 2014. Intermediate Accounting, Edisi Delapan. BPFE. Yogyakarta

Buvaneswari, R. \& S. Lakshmi. 2015. A study on financial statement analysis of sriram perfumes, trich. International Journal of Advanced Research in Management and Social Science, 4 (7).

Fauziah S. 2013. Produktivitas tenaga kerja karyawan pemanen dan pemupuk (Studi Kasus: $\quad$ PT Perkebunan Nusantara IV Sawit Langkat, Kecamatan Padang Tualang, Kabupaten Langkat). Jurnal Sosial Ekonomi Agrikultur dan Agribisnis Nomor 3 Volume 2, Maret 2013. Sumatra Utara.

Harahap, Sofyan Syafri. 2008. Analisis Kritis atas Laporan Keuangan. Jakarta : PT. Raja Grafindo Persada.

Kasmir. 2012. Analisis Laporan Keuangan. Raja Grafindo.

Manurung SR. 2012. Faktor Faktor Yang Mempengaruhi

\begin{tabular}{lrrr} 
Produktivitas & \multicolumn{2}{r}{ Tenaga } & Kerja \\
Karyawan & \multicolumn{2}{c}{ Pemanen } & Dan \\
Pemupuk & di & PT & Perkebunan \\
Nusantara & & IV. & Skripsi.
\end{tabular}

Fakultas Pertanian. Universitas Sumatra Utara.

Rahmalia, D., M. I. Affandi, \& K. Murniati. 2016. Strategi pengembangan pembiayaan agribisnis padakoperasi simpan pinjam pola syariah di Lampung Tengah. Prosiding Seminar Nasional Hasil- $\quad$ Hasil PPM IPB: 225-238.

Repbulik Indonesia. 2003. Undang Undang Nomor 19 Tahun 2003 Tentang Badan Usaha Milik Negara (BUMN). Arsip Indonesia. Jakarta

Sugiyono. 2013\2. Metode Penelitian Bisnis. CV. Alfabeta. Bandung. Surat Keputusan Menteri BUMN NO: $\quad$ KEP-100/MBU/2002 Tentang Penilaian Tingkat Kesehatan BUMN

Trimo, Lucyan dkk. 2017 Kajian Pengembangan Agroindustri Berbasis Teh Rakyat Study of Tea Small Holder Agroindustry Development. Jurnal Rekaya Hijau ISSN 2550-1070. Volumen 1 No 2, Juli 2017

William H. 2013. Produktivitas tenaga kerja di PT Eastern Sumatera Indonesia, Kebun Bukit Maradja Estate. Jurnal Sosial Ekonomi Agrikultur dan Agribisnis Nomor 2 Volume 2, Februari 2013. Sumatra Utara 